\title{
PENERAPAN PRODUKSI BERSIH DI INDUSTRI PEMINDANGAN IKAN DESA BAJOMULYO KECAMATAN JUWANA, PATI
}

\section{APPLICATION OF CLEANER PRODUCTION ON BOILED FISH INDUSTRY IN BAJOMULYO VILLAGE, JUWANA PATI REGENCY}

\author{
Arieyanti Dwi Astuti \\ Kantor Penelitian dan Pengembangan Kabupaten Pati \\ E-mail: ariey_antik@yahoo.com
}

Naskah Masuk: 26 Maret 2015 Naskah Revisi: 2 April 2015 Naskah Diterima: 17 April 2015

\begin{abstract}
Boiled fish industry in Bajomulyo, Juwana causes environmental degradation because of it's waste. One of the causes of environmental degradation is wastewater that the waste is not managed properly. This study aimed: 1) to describe the activity of boiled fish production; 2) to review cleaner production effort that can be applied in boiled fish industry. This is a descriptive research. Data were obtained from interviews, field observations and relevant literature. The results showed that: 1) The process of boiled fish production starts from raw material preparation (thawing) if the raw fish were obtained from cold storage. Next, the fish washed and laid out in baskets and then boiled with salt water. Waste generated from this industry is in solid and liquid forms; 2) The approach of cleaner production in boiled fish industry can be applied by further processing of waste generated by simple processing. That process will produce diversified products, i.e. raw material of animal feed ingredients that have better economic value. Moreover, utilization of the waste will reduce environmental pollution load.
\end{abstract}

Keywords: boiled fish industry, cleaner production, product diversification

\begin{abstract}
ABSTRAK
Industri pemindangan ikan di Bajomulyo Juwana menyebabkan penurunan kualitas lingkungan akibat limbah yang dihasilkannya. Penyebab penurunan kualitas lingkungan salah satunya disebabkan limbah cair yang tidak terkelola dengan baik. Penelitian ini bertujuan untuk mendeskripsikan aktivitas produksi ikan pindang serta melakukan pengkajian tentang upaya produksi bersih yang bisa diterapkan dalam industri ikan pindang. Penelitian ini merupakan penelitian deskriptif. Data diperoleh dari hasil wawancara, observasi lapangan dan literatur yang relevan. Hasil penelitian menunjukkan bahwa: 1) Proses produksi ikan pindang dimulai dari penyiapan bahan baku (thawing) jika ikan yang digunakan diperoleh dari cold storage. Setelah itu, ikan dicuci dan ditata di besek untuk kemudian direbus dengan air garam. Limbah yang dihasilkan dari industri ini berupa limbah padat dan limbah cair; 2) Pendekatan produksi bersih pada industri pemindangan ikan dapat dilakukan dengan mengolah lebih lanjut limbah yang dihasilkan dengan pengolahan sederhana. Dari pengolahan tersebut, dihasilkan diversifikasi produk berupa bahan baku pakan ternak yang memiliki nilai ekonomis yang lebih baik serta pemanfaatan limbah yang akan mengurangi beban pencemaran terhadap lingkungan.
\end{abstract}

Kata kunci: diversifikasi produk, industri pemindangan ikan, produksi bersih 


\section{PENDAHULUAN}

Pada awalnya strategi pengelolaan lingkungan mengacu pada strategi dengan pendekatan pada daya dukung lingkungan (carrying capacity). Namun pada kenyataannya konsep ini sukar diterapkan, karena berbagai masalah yang timbul ketika pencemaran yang terjadi sudah melebihi daya dukung yang bisa ditampung lingkungan. Strategi pengelolaan lingkungan kemudian berubah menjadi upaya untuk memecahkan masalah pencemaran dengan mengolah limbah yang dihasilkan (end of pipe treatment). Namun cara ini juga masih belum bisa mengatasi permasalahan lingkungan yang semakin memburuk, terlihat dari tidak adanya instalasi atau unit pengolah limbah baik pada beberapa industri berskala besar maupun industri rumah tangga. Hal ini dimungkinkan terkait dengan masalah teknis dalam pembuatan instalasi atau unit pengolah limbah yang membutuhkan lahan yang cukup luas serta mahalnya biaya pembangunan dan operasionalnya. Pada akhirnya strategi pengelolaan lingkungan berubah menjadi upaya pencegahan (prevention) yang kemudian konsep ini dikenal dengan prinsip Produksi Bersih (Cleaner Production). Produksi bersih umumnya dilakukan dalam suatu kegiatan industri untuk tujuan efisiensi dan peningkatan keuntungan dengan tetap memperhatikan kelestarian lingkungan. Salah satu industri yang dalam produksinya masih dilakukan secara tradisonal dan banyak menghasilkan limbah yang berpotensi untuk dimanfaatkan adalah industri pemindangan ikan.

Di Jawa Tengah, salah satu daerah yang banyak menghasilkan ikan pindang adalah Kabupaten Pati. Menurut data dari Dislautkan Kab. Pati (2013), industri pemindangan ikan di Kabupaten Pati memiliki kurang lebih 100 unit pengolahan ikan atau sekitar 18,52\% dari total industri pengolahan ikan di Kabupaten Pati. Hasil produksi ikan pindang di Kabupaten Pati mencapai 43 kilo ton pada tahun 2011, dimana jumlah ini mengalami peningkatan signifikan dari tahun 2010 yang hanya menghasilkan sekitar 27 kilo ton ikan pindang. Hal tersebut menunjukkan bahwa permintaan akan ikan pindang terus meningkat. Industri pemindangan ikan di Kabupaten Pati tersebar di 8 (delapan) kecamatan, yaitu Kecamatan Juwana, Kecamatan Tayu, Kecamatan Wedarijaksa, Kecamatan Pati, Kecamatan Dukuhseti, Kecamatan Margoyoso, Kecamatan Batangan dan Kecamatan Jakenan. Dari total industri pemindangan di 8 kecamatan tersebut, $47,12 \%$ nya terdapat di Kecamatan Juwana yang tersebar di beberapa desa, diantaranya 24,09\% terdapat di Desa Dukutalit dan 21,69\% di Desa Bajomulyo (Dislautkan Kab. Pati, 2013).

Proses pemindangan ikan di Kabupaten Pati rata-rata dilakukan secara tradisional menggunakan peralatan yang sederhana serta kurang memperhatikan aspek sanitasi dan kehigienisan sehingga dikhawatirkan akan berdampak pada kesehatan dan lingkungan sekitar industri pengolahan ikan tersebut. Dampak lingkungan yang umum terjadi sebagai akibat dari kegiatan pemindangan ikan adalah limbah cair yang dihasilkan dari proses pencucian dan perebusan ikan dengan garam.

Desa Bajomulyo merupakan salah satu desa di Kecamatan Juwana yang menjadi sentra ikan pindang di Kabupaten Pati. Menurut data Dislautkan Kab. Pati (2013), setiap harinya $2-3$ ton ikan pindang dari berbagai jenis ikan mampu dihasilkan dari 1 (satu) industri pemindangan ikan di desa tersebut. Pemindangan ikan banyak terpusat di RT 3 RW 1 dan RT 4 RW 2 Desa Bajomulyo. Beberapa industri pemindangan ikan tersebut sudah melakukan pemindangan 
ikan sejak berpuluh-puluh tahun yang lalu dan merupakan salah satu aktivitas ekonomi warga Desa Bajomulyo yang berbasis rumah tangga. Industri pemindangan ikan banyak dilakukan di area TPI Bajomulyo yang lokasinya berbatasan dengan Sungai Juwana. Pemilihan lokasi di area TPI Bajomulyo berdasarkan kemudahan akses, baik akses dalam mendapatkan bahan baku berupa ikan, maupun akses dalam membuang limbah cair.

Kegiatan usaha perikanan mulai dari pendaratan ikan segar, penanganan dan pengolahan ikan umumnya selalu menghasilkan limbah, baik limbah cair, limbah padat maupun udara (berupa bau). Limbah dari industri pengolahan hasil perikanan termasuk industri bahan pangan yang mengandung senyawa organik tinggi sehingga mudah mengalami pembusukan oleh mikroorganisme yang pada akhirnya berpotensi menimbulkan pencemaran lingkungan. Hal ini sesuai dengan penelitian Sudarmaji dalam Hikamah dan Mubarok (2012), yang menyatakan bahwa jika air limbah industri pemindangan ikan dibuang ke sungai akan menyebabkan pencemaran air sungai dikarenakan polutan yang terdapat pada air limbah tersebut.

Untuk menyikapi hal tersebut diperlukan suatu upaya perbaikan kualitas lingkungan, salah satunya dengan melakukan pengelolaan lingkungan yang tepat. Upaya pengelolaan lingkungan diarahkan pada perbaikan kinerja lingkungan yang diharapkan dapat

menghasilkan suatu bentuk pengelolaan lingkungan yang mampu mengakomodir kepentingan para pengusaha ikan pindang, masyarakat dan pemerintah daerah, salah satunya dengan penerapan produksi bersih (Cleaner Production). Tujuan penelitian ini adalah untuk: 1) Mendeskripsikan aktivitas produksi ikan pindang dalam suatu industri; dan 2) Melakukan pengkajian tentang upaya produksi bersih yang bisa diterapkan dalam industri ikan pindang tersebut agar produksi menjadi lebih efektif baik dari segi biaya, waktu, tenaga serta ramah lingkungan.

\section{TINJAUAN PUSTAKA}

\section{Produksi Bersih}

Produksi $\begin{gathered}\text { bersih } \\ \text { (Cleaner } \\ \text { strategi } \\ \text { pengelolaan lingkungan yang sifatnya }\end{gathered}$
mengarah pada pencegahan (preventif)
dan terpadu agar dapat diterapkan pada
seluruh siklus produksi. Hal tersebut
bertujuan meningkatkan produktivitas
dengan memberikan tingkat efisiensi yang
lebih baik dalam penggunaan bahan
mentah, energi dan air, mendorong
performansi lingkungan yang lebih baik
melalui sumber-sumber pembangkit
limbah dan emisi serta mereduksi dampak
produk terhadap lingkungan melalui
rancangan yang ramah lingkungan,
namun efektif dari segi biaya (Ma'ruf
dkk, 2013). Secara terperinci, definisi dan
ruang lingkup produksi bersih dijelaskan
dalam Gambar 1.




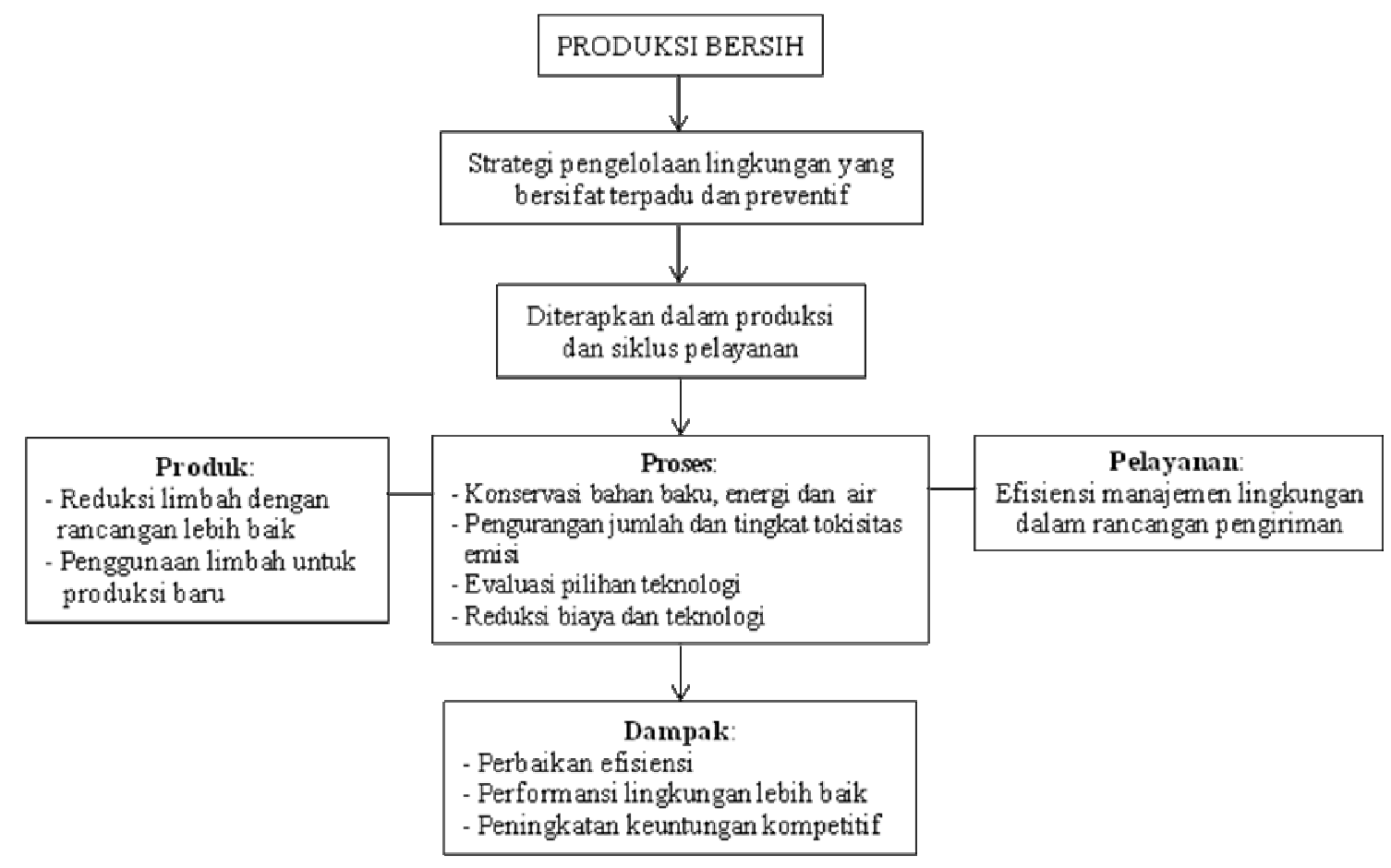

Gambar 1.

Definisi dan Ruang Lingkup Produksi Bersih

Sumber: UNIDO 2002 dalam Indrasti dan Fauzi (2009)

Hal serupa juga diungkapkan Weston dan Stuckey dalam Ibrahim (2004) yang menyatakan bahwa produksi bersih mampu mereduksi tingkat emisi pencemar dan produksi limbah pada sumbernya, dan membuat efisien dari penggunaan bahan baku, energi dan utilitas, sehingga pada akhirnya dapat mereduksi dampak negatif terhadap lingkungan.

\section{Industri Pemindangan Ikan}

Ikan merupakan komoditas bahan pangan yang tergolong mudah dan cepat mengalami penurunan mutu (perishable food). Hal ini dikarenakan tingginya kandungan protein dan air pada tubuhnya. Proses pembusukan ikan dapat disebabkan oleh aktivitas enzim yang terdapat di dalam tubuh ikan sendiri, aktivitas mikroorganisme atau proses oksidasi pada lemak tubuh ikan oleh oksigen dari udara. Aktivitas mikroorganisme terjadi pada seluruh lapisan daging ikan, terutama insang, isi perut dan kulit. Dalam beraktivitas, mikroorganisme dibantu oleh enzim. Beberapa enzim pada mulanya berfungsi sebagai katalisator proses-proses metabolik lalu berubah fungsi menjadi penghancur jaringan tubuh ikan (Millah dan Sukesi, 2009).

Pemindangan ikan adalah salah satu cara mengawetkan ikan secara sederhana dan singkat, dengan memanfaatkan sifatsifat kimiawi terutama penggunaan suhu yang merupakan prinsip dasar dalam bidang pengolahan hasil perikanan. Jenis ikan yang sering dijadikan pindang adalah kembung (Rastrelliger), Layang (Decapterus), Tongkol (Euthynnus) atau Caranx sp. Ikan pindang dari Kabupaten Pati dikenal memiliki rasa yang gurih tidak terlalu asin sehingga cocok digunakan sebagai lauk untuk pemenuhan 
kebutuhan protein harian. Hal inilah yang menyebabkan industri pemindangan ikan tetap bertahan dan semakin berkembang. Permintaan pasar akan ikan pindang terus mengalami peningkatan. Berdasarkan hasil observasi dan wawancara dengan pemilik industri pemindangan ikan, permintaan ikan pindang dari Juwana Pati tidak hanya berasal dari lokal saja tetapi juga dari luar daerah seperti Solo, Semarang, Yogyakarta, Wonogiri, Klaten, Sragen, Majenang, Prambanan, Wonosobo, Temanggung dan Kudus.

\section{METODE PENELITIAN}

Lokasi penelitian dilakukan di industri pemindangan ikan di Desa Bajomulyo, Kecamatan Juwana Kabupaten Pati pada bulan Maret-Agustus 2014. Jenis data yang diperlukan dalam penelitian ini adalah data primer dan data sekunder. Data primer diperoleh dari wawancara dan observasi langsung yang dititikberatkan pada tahapan proses produksi ikan pindang di Desa Bajomulyo, Juwana. Sedangkan data sekunder diperoleh melalui dokumen dari instansi terkait dan berbagai literatur yang relevan. Penelitian ini merupakan penelitian yang bersifat deskriptif.

\section{HASIL DAN PEMBAHASAN}

\section{Tahapan Proses Produksi Ikan Pindang}

Industri ikan pindang di Desa Bajomulyo, Juwana rata-rata memiliki jumlah pekerja sekitar 40-50 orang. Jumlah ikan pindang yang diproduksi berkisar antara $2-3$ ton/hari, dan akan meningkat sampai 5 ton/hari saat bulan puasa. Kualitas ikan pindang salah satunya dipengaruhi oleh bahan baku ikan yang digunakan. Bahan baku yang biasa digunakan ada 2 (dua) jenis yaitu ikan segar yang tidak dibekukan dan ikan segar yang sudah dibekukan (cold storage). Harga ikan beku sedikit lebih mahal dibandingkan harga ikan segar karena adanya biaya untuk proses pembekuan.
Penggunaan bahan baku ini tergantung dari ketersediaan bahan baku yang ada dan permintaan konsumen. Konsumen lebih menyukai ikan pindang dari bahan baku ikan beku karena lebih kesat, bentuk utuh, lebih kenyal dan rasanya lebih gurih. Ikan beku lebih berkualitas dari ikan segar karena proses pembekuan ikan berlangsung di kapal sesaat setelah ikan ditangkap, sehingga kesegaran ikan terjaga sampai saat proses produksi dilakukan, seperti bentuk ikan yang masih utuh dan kencang, kulit mulus (tidak ada yang sobek), dan isi perut yang belum keluar.

Berdasarkan pengamatan di lokasi penelitian, terdapat sedikit perbedaan pada proses produksi pemindangan ikan. Pada proses pemindangan dengan bahan baku ikan segar yang tidak dibekukan, ikan segar yang telah disortir, dicuci dan dibersihkan akan langsung ditambahkan garam sebelum ditata di besek untuk kemudian direbus dengan air garam. Proses pencucian ikan dilakukan dengan mengguyur ikan menggunakan air. Sedangkan untuk ikan beku, setelah dicairkan, disortir, dicuci dan dibersihkan, ikan langsung ditata di besek dan direbus air garam tanpa ditambahkan garam sebelumnya seperti pada proses pemindangan dengan ikan segar. Penambahan garam pada ikan segar dilakukan untuk menjaga kualitas ikan pindang yang dihasilkan. Sebelum ikan ditata di besek, perut ikan ditutup dengan kertas untuk mencegah isi perut ikan keluar saat direbus. Setelah tertata di besek, ikan akan direbus di larutan garam mendidih selama kurang lebih 15 - 20 menit. Setelah itu ikan ditiriskan untuk kemudian siap dipasarkan.

\section{Identifikasi Sumber Limbah}

Pada proses pembuatan ikan pindang dihasilkan beberapa limbah saat proses produksinya, baik limbah padat maupun limbah cair. Limbah padat dihasilkan saat penanganan bahan baku (thawing) jika bahan baku yang digunakan berasal dari cold storage. Pada 
proses tersebut dihasilkan limbah padat berupa kardus dan plastik pembungkus ikan.

Setelah dicuci dan dibersihkan, ikan akan mengalami proses penyortiran. Penyortiran ikan ini dimaksudkan untuk menyisihkan ikan yang tidak utuh. Kemudian ikan yang bagus akan ditata di besek setelah sebelumnya perut ikan ditutup kertas untuk mencegah isi perut ikan keluar saat direbus, 1 (satu) besek biasanya diisi $2-3$ ekor ikan tergantung ukuran ikan. Dari proses ini dihasilkan limbah padat berupa ikan yang tidak utuh atau bagian tubuh ikan yang tidak bisa digunakan pada proses produksi selanjutnya, serta limbah cair berupa air hasil pencucian ikan.

$$
\text { Proses selanjutnya adalah }
$$

perebusan ikan dalam larutan garam. Ikan yang sudah ditata di besek akan direbus. Perebusan ikan ini dilakukan sekaligus dengan beseknya dengan tujuan agar ikan tidak berserakan saat direbus. Perebusan dilakukan pada bak perebusan yang berbahan bakar kayu bakar. Pada proses ini dihasilkan limbah cair berupa air sisa perebusan yang pekat, berbuih dan berwarna cokelat. Air limbah hasil perebusan ikan ini mengandung protein terlarut tinggi.

\section{Pendekatan Produksi Bersih Industri Pemindangan Ikan}

Limbah padat yang dihasilkan dari industri ikan pindang diantaranya kardus dan plastik bekas pembungkus ikan beku dari cold storage, serta ikan yang tidak tersortir (ikan yang tidak utuh). Kardus dan plastik bekas pembungkus ikan sudah dikelola secara sederhana yaitu dengan dijual ke para pengepul barang bekas. Untuk ikan yang tidak tersortir biasanya dibeli murah oleh warga sekitar sebagai lauk sehari-hari. Meskipun begitu, masih banyak ditemukan ceceran bagian-bagian tubuh ikan yang pada akhirnya menjadi limbah. Di akhir produksi, ceceran bagian tubuh ikan ini akan disapu menggunakan air yang pada akhirnya bercampur dengan air cucian ikan. Untuk lebih memaksimalkan penerapan produksi bersih pada industri pemindangan ikan, kardus, plastik pembungkus ikan dan ikan yang tidak tersortir seharusnya ditata dan dipisahkan pada tempat-tempat kering yang sudah disediakan. Setelah tertata, limbah tersebut kemudian didata untuk mengetahui banyaknya limbah yang bisa dimanfaatkan.

Limbah cair yang dihasilkan dari proses pemindangan ikan sampai sekarang masih belum teratasi dan dikhawatirkan akan semakin memperparah kondisi lingkungan di sekitarnya. Limbah cair yang berasal dari proses pencucian dan air sisa perebusan ikan oleh pihak industri pindang kemudian dialirkan langsung ke Sungai Juwana yang berada tepat di belakang lokasi industri di Desa Bajomulyo tanpa pengolahan terlebih dahulu. Pembuangan limbah dilakukan sehari sekali pada sore/malam hari setelah proses produksi selesai. Jika dalam sehari limbah tersebut tidak dibuang, maka dapat dipastikan akan mengeluarkan bau tidak sedap akibat pembusukan limbah.

Limbah cair pemindangan ikan banyak mengandung bahan yang berpotensi sebagai pencemar lingkungan akibat tingginya kandungan protein, lemak, garam dan kandungan-kandungan lain sehingga memerlukan treatment tertentu sebelum limbah dibuang ke lingkungan. Tingginya volume limbah juga menjadi kendala dalam pengelolaan limbah di industri pemindangan ikan. Untuk menghindari proses pengolahan limbah cair, sejak awal diusahakan agar dalam proses produksinya menerapkan prinsip produksi bersih, terutama dalam penggunaan dan pengelolaan kebutuhan air.

Pendekatan produksi bersih yang bisa dilakukan adalah dengan upaya pencegahan terjadinya limbah (pollution prevention) yang tepat untuk mengurangi timbulan limbah dan diusahakan output dari proses tersebut dapat menghasilkan produk baru yang memiliki nilai ekonomis yang lebih baik. Secara skematis, recovery bahan sisa (limbah) dapat dilihat pada gambar 2 . 


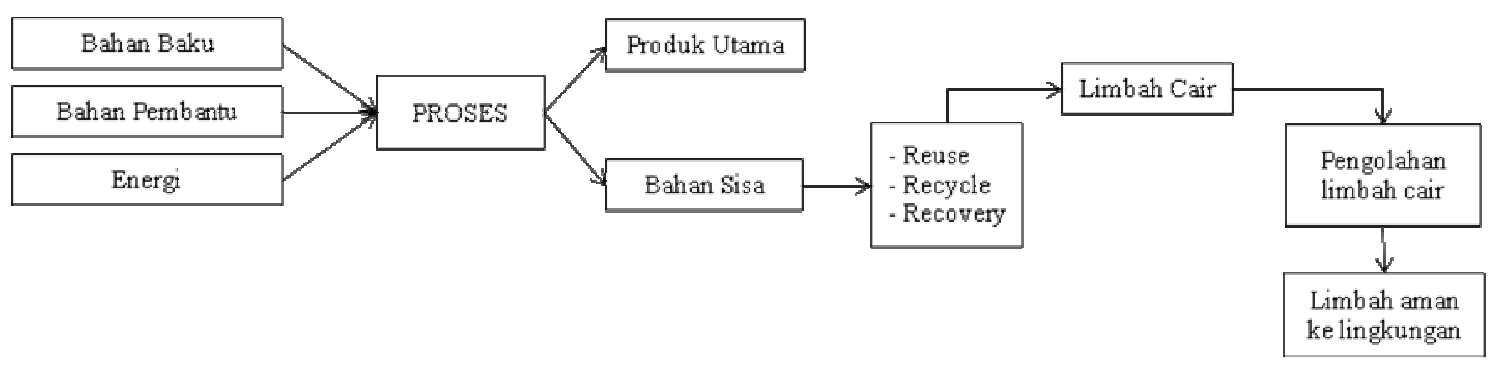

Gambar 2.

Skema Recovery Limbah Industri Pemindangan Ikan

Pada Gambar 2 terlihat adanya proses reuse, recycle dan recovery yang dapat diterapkan pada industri pemindangan ikan. Salah satunya adalah dengan menghemat penggunaan air bersih terutama pada proses pencucian ikan, yang dalam prosesnya dilakukan dengan cara mengguyur ikan dengan air menggunakan selang. Cara ini mengakibatkan pemborosan air bersih. Pendekatan produksi bersih yang bisa dilakukan pada proses ini adalah membuat 2 (dua) bak tampungan air bersih untuk proses pencucian ikan. Ikan yang akan dicuci dimasukkan pada bak pertama dengan menggunakan keranjang untuk mencegah ikan berserakan saat dicuci. Setelah dicuci di bak pertama, ikan dipindahkan ke bak kedua untuk dicuci kembali. Dari proses pencucian ini, air di bak pertama menjadi lebih keruh dibandingkan air di bak kedua. Setelah terlihat keruh dan pekat akibat beberapa kali proses pencucian ikan, air pada bak pertama bisa diganti menggunakan air pada bak kedua, dan air pada bak kedua diganti dengan air baru. Proses pencucian ikan dengan cara seperti ini lebih menghemat air dibandingkan dengan cara pengguyuran ikan menggunakan selang sehingga bisa meminimalisir limbah cair yang dihasilkan dari proses ini.

Untuk mempermudah penanganan limbah cair industri pemindangan ikan, hal pertama yang harus dilakukan adalah memisahkan antara tampungan limbah cair dari proses pencucian ikan dengan tampungan limbah cair dari air sisa perebusan ikan, berdasarkan pertimbangan bahwa kedua limbah cair tersebut memiliki karakteristik limbah yang berbeda. Dikhawatirkan nantinya ketika limbah tersebut dicampur, penanganan limbah tidak akan maksimal.

Sebelum masuk ke bak penampung, limbah cair dari proses pencucian ikan akan mengalami penyaringan. Hal ini bertujuan untuk memisahkan air dengan padatannya seperti ceceran bagian tubuh ikan, insang, isi perut atau kotorankotoran lainnya yang terbawa air cucian ikan. Padatan yang tersaring bisa langsung dimanfaatkan sebagai pakan ternak. Sedangkan cairannya, bisa diolah secara sederhana menggunakan kolam septik peresapan. Hal yang sama juga dilakukan pada limbah cair dari proses perebusan ikan, dimana sebelum masuk ke bak tampungan, limbah cair ini harus disaring terlebih dahulu sehingga padatan yang terdapat didalamnya tertahan untuk kemudian bisa dimanfaatkan sebagai pakan ternak. Limbah cair dari proses perebusan ikan yang sudah lolos saringan ditempatkan pada bak tampungan tersendiri terpisah dengan bak penampungan limbah cair dari proses pencucian ikan. Limbah cair ini kemudian diolah secara sederhana menggunakan koagulan kitosan untuk mendapatkan limbah cair yang aman dibuang ke lingkungan. Skema penerapan pendekatan produksi bersih di industri pemindangan ikan Bajomulyo, Juwana yang bisa dilakukan disajikan pada Gambar 3. 


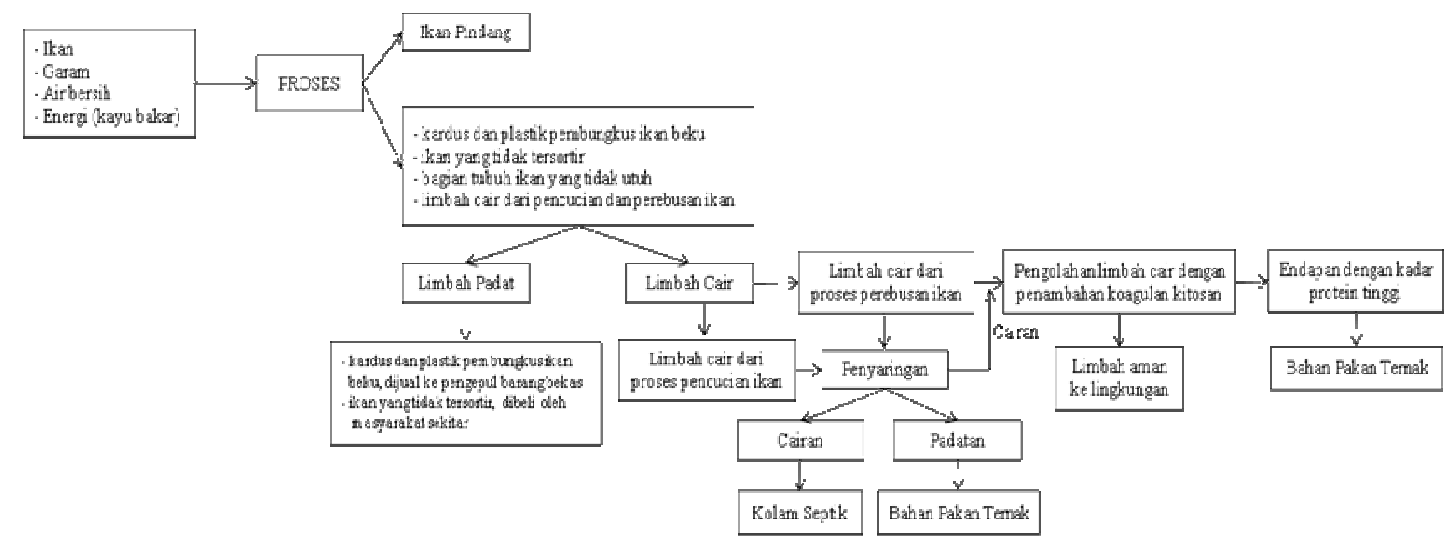

Gambar 3.

Skema Penerapan Produksi Bersih pada Industri Pemindangan Ikan

Gambar 3 diatas menjelaskan bahwa limbah cair dari industri pemindangan ikan dapat diolah sedemikian rupa sehingga menghasilkan bahan baku pakan ternak. Bahan baku ternak diperoleh dari limbah cair pemindangan ikan setelah melewati proses pengolahan koagulasi dengan koagulan kitosan. Kitosan dapat memudahkan terjadinya pemisahan protein dan filtrat pada limbah cair industri pemindangan ikan sehingga mengurangi beban pencemaran ketika limbah cair tersebut dibuang ke lingkungan. Protein yang dihasilkan bisa dimanfaatkan sebagai bahan baku pakan ternak. Seperti pada penelitian Murniati (2007), bahwa protein yang terdapat pada limbah cair sisa perebusan ikan sangat berpotensi digunakan sebagai pakan ternak. Pada penelitian ini, penambahan koagulan kitosan sebesar $1000 \mathrm{mg} / \mathrm{l}$ dengan pH 7 mampu menghasilkan endapan dengan kadar protein $50,56 \%$. Dari proses pengolahan limbah cair ini, pada akhirnya diperoleh limbah cair yang aman dibuang ke lingkungan.

Hal ini bisa diterapkan dalam pengolahan sederhana limbah cair industri pemindangan ikan di kawasan Bajomulyo, Juwana. Selain mengurangi beban pencemaran terhadap lingkungan, pengolahan sederhana ini juga bisa menciptakan tambahan pendapatan dengan menjual hasil pengolahan yang dapat dimanfaatkan sebagai bahan pakan ternak.

\section{KESIMPULAN DAN SARAN}

\section{Kesimpulan}

1. Proses produksi ikan pindang dimulai dari penyiapan bahan baku (thawing) jika ikan yang digunakan diperoleh dari cold storage. Setelah itu, ikan dicuci dan ditata di besek untuk kemudian direbus dengan air garam. Limbah yang dihasilkan dari industri ini berupa limbah padat dan limbah cair. Limbah padat berupa kardus dan plastik pembungkus ikan serta ikan yang tidak tersortir, limbah cair dihasilkan dari proses pencucian ikan dan perebusan ikan.

2. Pendekatan produksi bersih pada industri pemindangan ikan dapat dilakukan dengan mengolah lebih lanjut limbah yang dihasilkan dengan pengolahan sederhana. Dari pengolahan tersebut, dihasilkan diversifikasi produk berupa bahan pakan ternak yang memiliki nilai ekonomis yang lebih baik serta pemanfaatan limbah yang akan mengurangi beban pencemaran terhadap lingkungan. 


\section{Saran}

Untuk menunjang pendekatan produksi bersih pada industri pemindangan ikan di atas, maka diperlukan perencanaan pengelolaan lingkungan di kawasan industri pemindangan ikan. Beberapa diantaranya adalah: 1) Merevitalisasi sentra pemindangan ikan di Bajomulyo, Juwana berupa penyediaan sarana prasarana yang sesuai peraturan perundangan seperti perbaikan drainase dan penyediaan pengolahan limbah terpadu; 2) Mensosialisasikan peraturan perundangan yang berkaitan dengan industri pemindangan ikan, teknologi tepat guna, inovasi produk, manajemen mutu terpadu perikanan sebagai upaya meningkatkan kualitas ikan pindang. Pengembangan teknologi tepat guna sangat bermanfaat untuk mengoptimalkan pelaksanaan produksi bersih pada industri serta dapat meningkatkan kesejahteraan para pengolah ikan pindang.

\section{DAFTAR PUSTAKA}

Dinas Kelautan dan Perikanan Kabupaten Pati. 2013. Daftar Pengolah Ikan Se-Kabupaten Pati Tahun 2013. Pati.

Hikamah, S. R., H. Mubarok. 2012. Studi Deskriptif Pengaruh Limbah Industri Perikanan Muncar, Banyuwangi Terhadap Lingkungan Sekitar. Bioshell 1(1): 1-12.
Ibrahim, B. 2004. Pendekatan Penerapan Produksi Bersih Pada Industri Pengolahan Hasil Perikanan. Buletin Teknologi Hasil Perikanan 7(1): 1-11.

Ma'ruf, M., K. Sukarti., E. Purnamasari., E. Sulistianto. 2013. Penerapan Produksi Bersih Pada Industri Pengolahan Terasi Skala Rumah Tangga di Dusun Selangan Laut Pesisir Bontang. Jurnal Ilmu Perikanan 18(2): 84-93.

Indrasti, N. S., A. M. Fauzi. 2009. Produksi Bersih. Bogor: IPB Press.

Millah, F., Sukesi. 2009. Produksi Abon Ikan Pari (Rayfish): Penenuan Kualitas Gizi Abon. Skripsi. Fakultas Matematika Ilmu Pengetahuan Alam. Surabaya: Institut Teknologi 10 November.

Murniati, D. 2007. Pemanfaatan Kitosan Sebagai Koagulan Untuk Memperoleh Kembali Protein Yang Dihasilkan Dari Limbah Cair Industri Pemindangan Ikan. Tesis. Sekolah Pasca Sarjana. Magister Teknik Kimia. Medan: Universitas Sumatera Utara.

\section{BIODATA PENULIS}

Arieyanti Dwi Astuti, Peneliti Muda Bidang Kepakaran Teknik Lingkungan di Kantor Penelitian dan Pengembangan Kabupaten Pati sejak tahun 2010. Lahir 24 Agustus 1984 di Pati. Pendidikan S1 Jurusan Teknik Lingkungan Fakultas Teknik Universitas Diponegoro. 